\title{
PENGELOLAAN SUMBER DAYA MANUSIA DI SMA NEGERI 5 MATARAM
}

\author{
Harmoko, Muntari, Hamidsyukrie \\ Universitas Mataram \\ MuhamadHR29@yahoo.co.id \\ Muntari_unram@yahoo.com \\ hamidsyukrie@yahoo.com
}

\begin{abstract}
Abstrak: Penelitian ini bertujuan untuk mendeskripsikan perencanaan, teknik, evaluasi, tindak lanjut, dan implikasinya pengelolaan SDM Di SMA Negeri 5 Mataram. Hasil penelitian yaitu: 1) Perencanaan pengelolaan SDM di SMA Negeri 5 Mataram: a) Mempertimbangan secara demokratis, b) Penempatan guru yang berkompoten dan profesional pertimbangan psikologis, c) Menjaga kualitas dan peningkatan SDM memanfaatkan sumber daya yang ahli di bidang IT, d) Di bentuk tim kecil dengan tugas menemukan permasalahan sekolah, e) Secara bersama melalui rapat kerja tahunan (RAKER), f) Kesejahteraan guru, g) Menyelesaikan masalah secara kekeluargaan. 2) Pengelolaan SDM (Guru) di SMA Negeri 5 Mataram: a) Memperkuat dan memperkokoh atribut Smala, iklim kerja humanis serta kultur (kebersamaan, keteladanan, dan (5S), b) Buadaya melek IT, c) Memiliki sasaran mutu, d) Pendekatan individual (supervisi klinis). 3) Teknik evaluasi pengelolaan SDM (Guru) di SMA Negeri 5 Mataram: a) membangun kerja sama tim, b) kesadaran pribadi, reward dan 3) penerpan program unggulan $5 S$, c) aturan tidak terlalu ketat, d) Program kerja, silabus, RPP sudah terjadwal khusus diawal tahun pelajaran secara serentak di kontrol kepala sekolah, e) menjadikan mereka (guru) mampu bersatu, berkerja sama, memahami, menerima satu sama lain menuju tujuan bersama, f) Guru-guru di Smala bersikap sesuai tuntutan yang tercermin 4 kompetensi, g) pemanfaatan guru produktif untuk kreatif dalam bekerja, kemampuan computer mereka di atas rata-rata, mampu membuat buku pedoman pendidikn SMA Negeri 5 Mataram, dan Guru IN (Instruktur Nasional) dan guru instruktur provinsi, h) Kepemimpinan partisipan, i) Kegiatan menjadi Pembina, panitia/mengawas, pelatihan, seminar, sosialisasi, dan sebagainnya. 4) Tindak lanjut dari hasil pengelolaan SDM(Guru) di SMA Negeri 5 Mataram: a) mempertimbangkan 4 model manajemen pengelolaan SDM, b) Mempertimbangkan kondisi internal dan eksternal, c) Mempersiapkan prioritas melet IT, d) Menyesuaikan perubahan eksternal, e) Menggunakan analisis SWOT d, f) Menyatukan persepsi guru, g) Melakukan koordinasi dengan bawahan atas tupoksi yang telah dibebankan, h) Mempertimbangkan secara professional dan secara psikologis, i) Memperkuat sistem yang sudah berjalan, j) Fokus pada visi misi dan tujuan sekolah. 5) Implikasi pelaksanaan pengelolaan SDM (Guru) di SMA Negeri 5 Mataram: a) Guru-guru dengan rasa kekeluargaan, b) rotasi tugas pertimbangan kualitas kerjanya, c) Pemberian insentif, d) Memiliki tim yang kuat, e) Komitmen dan kerja sama guru.
\end{abstract}

Kata kunci: Pengelolaan Sumber Daya Manusia.

Abstract: Human Resources Management at Senior High School 5 In Mataram City. This study aimed to describe the planning, engineering, evaluation, follow-up, and the 
implications for human resource management at Senior High School 5 In Mataram City. The results of the research are: 1) Planning human resource management at Senior High School 5 In Mataram City: a) Considering the democratic way, b) Placement teacher is competent and professional consideration of psychological, c) Maintaining the quality and improvement of HR exploit the resources of experts in the field of technology, d) in the form of a small team with the task of finding a school problem, e) together with the annual working meeting, f) Welfare teachers, g) Resolve issues amicably. 2) Human Resource Management (Master) at Senior High School 5 In Mataram City: a) Strengthen and reinforce the attributes Smala, work climate humanist and culture (togetherness, exemplary, and (5S), b) culture technology, c) Have quality objectives, d) Approach individual (clinical supervision). 3) Technical evaluation of human resource management (Master) at Senior High School 5 In Mataram City: a) build teamwork, b) personal awareness, reward and 3) the implementation of the flagship program 5S, c) the rules are not too strict, d) work program, syllabus, the lesson plan has been scheduled specifically at the beginning of the school year simultaneously in control of the school principal, e) made them (teachers) were able to come together, work together, understand, accept each other toward a common goal, $f$ ) teachers in Smala act according to the demands reflected 4 competence, $g$ ) the utilization of teachers productive for the creative work, the capability of their computers above the average, able to make the guidebook education at Senior High School 5 In Mataram City, and Master IN (National Instructors) and teacher instructor province, h) Leadership participants, $i$ ) Activities become coaches, committee/overseen, training, seminars, socialization. 4) The follow up of human resource management (Master) at Senior High School 5 In Mataram City: a) consider the four models of management of human resource management, b) Taking into account the internal and external conditions, c) to prepare priority technology areas, d) Adjust the external changes, e) Using SWOT analysis $d$, f) Putting the perception of teachers, g) to coordinate with subordinates on the duties that have been imposed, h) Consider professionally and psychologically, i) Strengthening the existing system, j) Focus on vision, mission and objectives of the school. 5) Implications of the implementation of human resource management (Master) at Senior High School 5 In Mataram City: a) teachers with a sense of kinship, b) rotation of duties consideration the quality of work, $c$ ) Incentives, d) Having a strong team, e) Commitments and cooperation teacher.

Keywords: Human Resource Management.

\section{PENDAHULUAN}

Sekolah yang memiliki sumber daya berkualitas adalah sekolah yang mampu memanfaatkan sumber daya manusia yang ada dengan memberikan peluang bagi guru-gurunya untuk mengikuti pelatihan, seminar, MGMP, dan sebagainya. Ketika guru-guru memiliki wawasan yang luas, memiliki pengetahuan, dan keterampilan yang baik, tidak menutup kemungkin sekolah tersebut akan maju dan menjadi favorit serta diminati oleh masyarakat umum untuk menyekolahkan anak-anaknya disekolah tersebut.

SMA Negeri 5 Mataram ini sebagai latar penelitian ini didasarkan pada pertimbangan: SMA Negeri 5 Mataram adalah sekolah SMA terbaik di Indonesia versi Depdiknas (Kemendiknas) tertanggal 9 Agustus 2014. Sekolah terbaik versi Depdiknas adalah sekolah yang tidak hanya unggul di bidang akademik dan non-akademik saja, melainkan juga unggul pada: kebersihan lingkungannya, suasana belajarmengajarnya menyenangkan, tenaga 
pendidik, dan sarana-prasaranya (infrastruktur) sesuai Standar Nasional Pendidikan (SNP).

Tyas dan Nurhikmahyanti (2014) dalam penelitian ditemukan bahwa Faktor pendorong EDS secara internal adalah (1) SDM; (2) koordinasi antar stakeholder; (3) komunikasi antar warga sekolah, secara eksternal dukungan dari Dinas dan motivasi dari LPMP. Puspitasari dan Mangkunegara (2015) dalam penelitian di temukan bahwa: secara simultan (bersama-sama) kecerdasan emosi dan stres kerja berpengaruh terhadap kinerja guru. Damayani, Purnamasari dan Kusdaryani (2016) dalam penelitian ditemukan bahwa: 1) konsep kultur sekolah tertuang dalam visi misi, tata tertib, 8 budaya disiplin guru, dan 10 budaya malu siswa; 2) konsep pendidikan ramah anak; 3) penguatan kultur sekolah berdasarkan berbagai kebiasaan positif sekolah.

Sumintono (2013) dalam penelitian ditemukan bahwa: interpretasi terhadap kebijakan sekolah unggul dalam konteks SBI mengalami perubahan di konteks sekolah, yang paling nyata adalah munculnya kelas standar internasional sebagai implementasi kebijakan tersebut. Pranoto (2013) dalam penelitian ditemukan bahwa: Terdapat hubungan positif dan signifikan antara supervisi pengawas dan motivasi kerja dengan kinerja guru.

Pengelolaan SDM (ILO, 2013: 3) merupakan proses menetapkan prioritas, rencana dan kegiatan dalam pengelolaan tenaga kerja harus selaras dengan tujuan organisasi secara keseluruhan yang fokusnya adalah untuk mendapatkan orang yang tepat di tempat yang tepat pada waktu yang tepat.

Wilson, Everard, \& Geoffrey (2004: 74) kemampuan untuk mengembangkan kurikulum dengan cara mencapai tujuan sebagai sekolah, tentu tergantung pada SDM yang tersedia. Namun, sangat penting untuk memastikan bahwa ekor tidak mengibaskan anjing, bahwa isi pendidikan tidak ditentukan oleh SDM yang paling mudah tersedia, tapi bagaimana ketersediaan tersebut bisa berkualitas sesuai dengan kebutuhan pembelajaran siswa.

Menurut Mulyasa (2007: 42-45) untuk mengelola SDM agar memiliki kecakapan, motivasi dan kreativitas secara maksimal, maka hendaknya melalui tahapan-tahapan: a) Identifikasi staf/pegawai, b) Penempatan, c) Penyesuaian diri, d) Evaluasi, e) Perbaikan, f) Kompensasi pegawai, dan g) Pemberhentian pegawai. Menurut Wahjosumidjo (2007), strategi kepegawaian memerlukan konsentrasi kepemimpinan dalam arti kesungguhan dalam mencapai tujuan organisasi yaitu memelihara para anggotanya, berinisiatif dan berkreativitas dalam melaksanakan tugas-tugasnya sehingga terjadi hubungan proses administrasi, yang pada akhirnya akan tercipta keserasian antara tujuan organisasi dan usaha-usaha individu. Evaluasi (Suryosubroto, 2004: 90-91) beberapa hal yang penting untuk dinilai dalam daftar penilian guru, yaitu: a) Kemampuan kerja, b) Kerajinan, c) Kepatuhan disiplin kerja, d) Rasa tanggung jawab terhadap tugas, e) Hubungan kerja sama, f) Kelakuan di dalam dan di luar dinas, g) Prakarsa (inisiatif), h) Kepemimpinan, dan i) Pekerjaan pada umumnya.

Terdapat beberapa hal yang harus diperhatikan dan dilaksanakan oleh kepala sekolah menurut Imronfauzi (2008) agar dapat mencapai efektivitas sekolah, yaitu: a) Sekolah harus secara terus menerus menyesuaikan dengan kondisi internal dan eksternal yang mutakhir; b) Mampu mengkoordinasikan dan mempersatukan usaha seluruh sumber daya manusia kea rah pencapaian tujuan; c) Perilaku sumber daya manusia kearah pencapaian tujuan dapat 
dipengaruhi secara positif apabila kepala sekolah mampu melakukan pendekatan secara manusiawai; d) SDM merupakan suatu komponen penting dari keseluruhan perencanaan organisasi; e) Dalam rangka pengelolaan, seorang kepala sekolah harus mampu menegakkan hubungan yang serasi antara tujuan sekolah dengan perilaku SDM yang ada; dan f) Dalam meningkatkan efektivitas dan efesiensi sekolah, fungsi sumber daya manusia harus ditumbuhkan sebagai satu kesatuan utama.

Pfeffer dalam (Elitan, 2002: 8) menegaskan bahwa suatu keunggulan kompetitif dapat dicapai melalui pengelolaan sumber daya manusia yang dimiliki perusahaan secara efektif. Hal ini dapat diperoleh dengan menerapkan praktik-praktik berikut secara saling berkaitan karena sulit untuk menangani suatu tindakan bila hanya diterapkan secara terpisah, yaitu: a) Keselamatan kerja (employment security), b) Keselektifan dalam perekrutan (selective in recruiting), c) Tingkat upah yang

\section{METODE PENELITIAN}

Penelitian ini menggunakan pendekatan kualitatif dengan memakai bentuk studi kasus eksplanotoris digunakan untuk menjawab "bagaimana dan mengapa" dengan tehnik observasi pelibatan (participant observation).

Jenis data yang dikaji dalam penelitian ini adalah wawancara, observasi, dan dokumentasi. Teknik snow-ball sampling. Subyek yang menjadi informan dalam penelitian ini adalah Kepala Sekolah, Waka

HASIL DAN PEMBAHASAN

1. Perencanaan pengelolaan SDM di SMA Negeri 5 Mataram

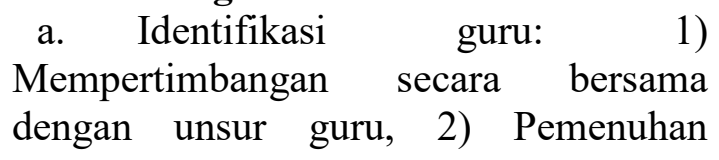

tinggi (high wages), d) Pemberian insentif (incentive pay), e) Hak kepemilikan karyawan (employee ownership), f) Information sharing, g) Partisipasi dan pemberdayaan (participation and empowerment), $\mathrm{h}$ ) Pengelolaan tim secara mandiri (self managed team), i) Pelatihan dan pengembangan ketrampilan (trainning and skill development), j) Cross Utilization and Cross Trainning, k) Symbolic egalitarian, 1) Wage compression, m) Promotion from within.

Melalui penelitian ini, ada hal yang menarik peneliti untuk mengakaji permasalahan pengelolaan sumber daya manusia di SMAN 5 Mataram, yang menjadi bagian dari 35 SMAN terbaik versi Kemendiknas. Pertanyaannya adalah bagaimana pengeloaan SDM di sekolah tersebut sehingga bisa masuk kategori terbaik dan kenapa sekolah lain tidak mampu bersaing? padahal hampir semua SDM (guru) sudah memenuhi kompetensi sebagai lulusan sarjana.

Kurikulum, Waka Kesiswaan, Waka Humas, Waka Sarpras, Kepala TU, Guru, Siswa, dan Perwakilan orang tua.

Teknik pengumpulan data dalam penelitian ini adalah: (1) wawancara tidak berstrukur (Unstructured Interview), (2) observasi partisipatif berperan serta, (3) studi dokumen. Analisis data terdiri dari tiga jalur kegiatan yang terjadi secara bersamaan yaitu: reduksi data, penyajian data, dan penarikan kesimpulan atau verifikasi.

kekurangan guru, 3) Penyegaran jabatan wakil kepala sekolah, 4) Mempertimbangkan harapan siswa dan harapan guru. Senada dengan apa yang disampaikan guru honorer, yaitu: "pertimbangan pengalaman 
berorganisasi, pengalaman kerja, informasi terpercaya, serta kompetensi pedagogik.

b. Penempatan: Menempatkan guru yang berkompeten dan profesional di bidang yang tepat lebih mempertimbangkan psikologis dengan, yaitu: 1) kesadaran, 2) komitmen dan loyalitas.

c. Penyesuaian diri: Fokus Smala dalam menjaga kualitas dan peningkatan SDM, adalah mengadakan pelatihan dan workshop bagi guru yang kurang kemampuan didalam IT. Tim kurikulum juga menyatakan bahwa guru aktif mengembangakan diri dibidang IT ataupun hal-hal yang dapat membantu menunjang kemajuan bagi pribadi dan kompetensi.

d. Evaluasi: Di Smala dibuat tim kecil (seluruh wakil kepala sekolah), melakukan evaluasi. Hasil temuan tim kecil akan dibahas dalam rapat kerja (RAKER) semester 1 atau RAKER 1 tahunan. RAKER penuh dinamika, masukan dan perbaikan program sebelumnya.

e. Perbaikan: Perencanaan ulang dan akan di masukan kedalam RKJM (rapat kerja jangka menengah) dan rapat kerja tahunan. Lebih lanjut wawancara dengan guru senior, mengatakan bahwa: tim kecil adalah guru yang professional dalam menjalankan tugas, sehinggah guru-guru sangat menerima masukan dan memperbaiki hal-hal yang kurang, baik itu soal kompetensi yang rendah dan halhal lain mengenai pengembangan diri.

f. Kompensasi pegawai: Sistem pemberian kompensasi Smala dilihat dari beban kerja, dan guru yang potensial akan diberikan bantuan dana untuk melanjutkan studi s2 serta bantuan dana untuk mengikuti kegiatan-kegiatan seperti diklat-diklat yang diadakan dipusat.

g. Pemberhentian pegawai: Langkah-langkah yang dilakukan sebagai sebuah sistem, yaitu: 1) mengamati dinamika yang dialami guru-guru, 2) kondisi ataupun masalah diselesaikan secara kekeluargaan, 3) pendekatan klinis, 4) Hubungan yang bersinergi, dan 5) potensi-potensi yang ada pada guruguru akan dikembangakan.

\section{Pengelolaan sumber daya manusia} (Guru) di SMA Negeri 5 Mataram

Kondisi guru dan siswanya sangat heterogen budaya dan agamannya. Sebagai pemimpin jelas harus memiliki jiwa nasionalisme dengan harapan tidak adalah lagi atribut lain kecuali atribut Smala. Tercermin pada tujuan Smala pada poin 8 yaitu meningkatkan iklim kerja yang kondusif, humanis, dan harmonis. Memiliki Kultur Sekolah yaitu: 1) Kebersamaan dan keteladanan, serta 2) Sapa, Sopan, Santun, Salam dan Senyum, (5S).

Sebagai pemimpin jangan sampai merusak budaya sekolah yg sudah terbentuk melainkan mengembangkan, salah satunya memberikan kesempatan kepada guru S2 dengan bantuan biaya, memberikan kesempatan kepada guruguru berinovasi dan ikut serta dalam setiap kegiatan sekolah baik pengiriman diklat dan pelatihan, serta kesejahteraan guru tetap diperhatikan. Selain pendidikan sekolah juga membudayakan melek IT dengan pelatihan yang tetap di adakan bagi guru-guru memiliki IT kurang sehingga pelaksanaan ujian CBT, serta PPDB online.

Hal ini di perkuat oleh isi program sekolah yaitu ada pada Sasaran mutu: a) mampu meraih juara dalam berbagai even kejuaraan akademik maupun non akademik minimal 40 kejuaraan, b) Meningkatnya kualitas SDM dan profesionalisme tenaga kependidikan sesuai bidang keahlian dan standar kompetensi, sekurang-kurangnya 6 guru dapat melanjutkan studi S2, c) Terlaksananya Sertifikasi berkualifikasi nasional/internasional, d) Meningkatnya 
kemampuan berbahasa asing (InggrisJerman) serta dapat menggunakan Bahasa Indonesia yang baik dan benar, e) Terealisasinya penerapan SMM mengacu ISO 9001: 2008 dalam penyelenggaraan diklat dan optimalisasi elemen diklat sebagai gugus kendali mutu, f) Meningkatnya standar pelayanan prima yang berfokus pada kepuasan masyarakat dan pelanggan, sehingga meningkatkan efisiensi dan efektivitas pembelajaran. Memimpin dengan cara situasional; ada kalanya perlu otoriter, ada kalanya demokratis dan ada kalannya liberal. Namun, yang paling utam komunikasi klinis dengan metode top down button up.

3. Analisis teknik evaluasi pengelolaan sumber daya manusia (Guru) di SMA Negeri 5 Mataram

a. Kemampuan kerja: Rasa kekeluargaan yang tinggi dan pengembangan diri, ikut aktif kegiatan workshop dan pelatihan. Kerja tim yang saling membantu kekurangan yang lain. Wawancara dengan Waka humas: guru Smala selalu menjadi pilihan menjadi guru IN (Instruktur Nasional) dan Instruktur provinsi NTB. Selain itu guru Smala yang berprestasi serta memiliki nilai UKG tertinggi di NTB, bahkan tertinggi ke 3 se-Indonesia untuk Guru bahasa Jermannya. Sisi lain hasil wawancara dengan siswa bahwa guru memiliki: kualitas mengajar yang baik, siswa termotivasi dengan pengelolaan kelas, dan kedekatan siswa dengan guru sangat terjalin harmonis.

b. Kerajinan: Di Smala ada kunci yang diterapkan yaitu kesadaran pribadi sebagai ciri khasnya, membuat guru-guru merasa sadar dan malu terlambat. Begitupun wawancara dengan guru BK "Sebagai reward guru-guru yang rajin akan mendapat honor.

c. Kepatuhan disiplin kerja: Guruguru aktif dengan ditanam nilai kesadaran akan tugasnya, aturan tidak terlalu ketat. Jika ada guru yang berhalangan masuk. Maka, guru yang serumpun/MGPM dan andaikan guru MGMP tidak bisa mengantikan. Tim kesiswaan, mengatakan sekolah sudah menjadi rumah kedua dan kekompakan bekerja yang membuat guru-guru menjadi betah dan nyaman disekolah, kegiatan melibatkan seluruh guru yang membuat guru merasa berfungsi di kegiatan tersebut.

d. Rasa tanggung jawab terhadap tugas: Membuat program kerja, silabus, RPP sudah terjadwal khusus diawal tahun pelajaran secara serentak di bawah kontrol kepala sekolah, dengan mengundang pengawas dan berberapa ahli K13 dengan memberikan workshop pada guru-guru. Begitupun kegiatan membuat soal Mid, UTS, UAS, Try Out, dan sebagainya mengikuti kalender pendidikan.

e. Hubungan kerja sama: Sudah menjadi makanan sehari-hari khalayak umum bahwa rasa kekeluargaan guru smala yang tinggi, hal ini dilihat kegiatan arisan setiap bulan yang diadakan secara bergilir di rumah guru-guru, kepala sekolah, ataupun tenaga kependidkan. Jika ada salah satu guru yang sakit, maka semua guru-guru menjenguk dan sekolah juga membantu dengan biaya untuk berobat serta sumbangan guru-guru. Selain itu kegiatan waktu luang guruguru akan berkumpul didepan lobi sekolah untuk bersenda gurau dan sangat mengembirakan. Seperti juga yang dirasakan guru-guru honor, sebagai junior kami merasakan kenyamanan dan sangat di akui, segala kegiatan wajib kami diikutkan, dan juga kami mendapatkan kesejahteraan.

f. Kelakuan di dalam dan di luar dinas: Guru-guru sangat memuaskan dilihat dari cara mereka bekerja, kedekatan mereka dengan siswa, walaupun ada konflik satu sama lain mereka tetap bekerja professional, kerja 
tim yang kuat, kekeluargaan yang terjalin, arisan setiap bulan dengan bergilir rumah-rumah mereka, pribadi yang supel, senior sangat ramah dengan juniornya. Intinya budaya kekeluargaan adalah ciri khas Smala, dan siapun yang datang harus mampu menyesuaiakan dengan budaya tersebut. Lebih lanjut siswa Smala berpendapat bahwa "jika bertemu di tempat umum biasanya guruguru sangat supel dan mau menegur sapa. Ketika di dalam kelas mereka sangat seru dengan dinamika mengajarnya, dan juga guru-guru sangat dekat dengan siswa secara emosional, sehingga terkadang kami lebih berani berpendapat, berdiskusi dan terkadang curhat masalah, karir, belajar, sosial, da bahkan masalah pribadi.

g. Prakarsa (inisiatif): Di Smala guru yang umur produktif sangat banyak, mereka sangat kreatif dalam bekerja, kemampuan computer mereka di atas rata-rata, mereka mampu membuat buku pedoman pendidikn SMA Negeri 5 Mataram, juara-juara mereka embat, dan Guru IN (Instruktur Nasional) dan instruktur provinsi. Begitupun hasil wawancara dengan tim kurikulum "Kemampuan dan kompetensi guru-guru umur produktif jangan diragukan lagi, mereka memiliki potensi atau keterampilan lebih.

h. Kepemimpinan: Sebagai kepala sekolah akan menjadi resiko jika membawa prinsip terlalu kaku atau keinginan sendiri, maka perlu mengenal budaya pemimpin sebelumnya dan melanjutkan tonggak kepemimpinan tanpa menghilangkan cara-cara yang sudah baik, kecuali berapa hal tambahan yang menurut saya masih kurang. Begitupun hasil wawancara dengan salah seorang siswa "soalnya cara guru dalam mengelola pembelajaran membuat kami senang, merasa diakui sebagai siswa dan juga tidak memaksakan siswa jika tidak mampu mengerjakan tugas, melainkan kami diajak mencoba review kembali yang belum dipahami.

i. Pekerjaan pada umumnya: Guru diberi kesempatan di ikutkan dalam semua kegiatan, baik tugas-tugas kepanitiaan, pembina ataupun pelatihan. Jadi, Smala sudah menjadi kebanggan dan kepuasan kerja, tidak hanya itu, penghargaan pada guru dengan kesranya juga luar biasa memuaskan.

\section{Tindak lanjut dari hasil pengelolaan sumber daya manusia (Guru) di SMA Negeri 5 Mataram}

a. Sekolah menyesuaikan kondisi internal dan eksternal yang mutakhir: Smala sangat cepat dalam merespon perubahan yang terjadi pada dunia pendidikan, baik itu perubahan pada aturan daerah maupun pada aturan pusat. Ada ciri smala yang menjadi prioritas ada melet IT. Jadi, jika guruguru menguasai IT segala perubahan akan mampu menyesuaikan dengan cepat dan tepat dan kerja $99 \%$ efektif dan efisien. Begitupun wawancara dengan tim kurikulum "tim kurikulum paham dan sadar betul akan berbagai perubahan, meresponnya tepat dengan cara menyesuaikannya. Lain halya dengan problem dan dinamika kondisi internal dan eksternal, biasanya kami menggunakan analisis SWOT.

b. Mengkoordinasikan dan mempersatukan SDM ke arah pencapaian tujuan: Guru harus memiliki pengalaman yang sama, tua-muda, senior-junior, PNS-honorer. Dengan membangun kerja tim yang kuat, kesejahteraan yang baik, dengan cara setiap tugas dan jabatan harus bergilir secara periodik, kecuali pada tugas profesional masing-masing guru. Lebih lanjut seperti yang di ceritakan oleh salah satu guru senior yang pertama kali mengajar sejak berdiri Smala "rasa memiliki Smala yang membuat kami tidak terlalu memikir siap yang menjabat dan bertugas, sebab pada 
endingnya apapun tugasnya kami tetap kerja tim serta jiwa kekeluargaan yang sangat kuat.

$\begin{array}{ccr}\text { c. Kepala } & \text { sekolah } & \text { mampu } \\ \text { melakukan } & \text { pendekatan } & \text { secara }\end{array}$
manusiawi: Pemimimpin yang baik adalah pemimpin yang mau mendengarkan bawahan, menampung segala aspirasi bawahan. Hal tersebut dilakukan dengan semua guru selalu di ajak berbicara 4 mata (komunkasi klinis). Seperti halnya yang disampaikan oleh guru-guru sekolah lain "kami berharap pak Rosidin bisa jadi kepala sekolah mereka dengan alasan sudah menjadi rahasia umum pendekatan dan cara beliau memimpin serta kesejahteraan yang diberikan pada bawahannya.

d. Sumber daya manusia merupakan suatu komponen penting dari keseluruhan perencanaan organisasi: Berapa hal yang harus diketahui yang sudah dilakukan di Smala, yaitu: 1) Tendensi yang baik sudah terbina; 2) Pendekatan kepribadian; 3) Pengawasan rutin; 4) sumbangan rutin yaitu sumbangan infak. Jika timbul masalah maka komunikasi klinis manjadi kunci penyelesaianya. Wawancara dengan tim kurikulum yaitu: 1) secara top down-button up; 2) membangun komunikasi yang intens dan penuh humoris; 3) setiap guru yang memiliki kelebihan pada potensi khusus; dan 4) seluruh guru harus menerima perbedaan agar terhindar konflik.

e. Kepala sekolah harus mampu menegakkan hubungan yang serasi antara tujuan sekolah dengan perilaku sumber daya manusia yang ada: menjaga nilai kekeluargaan dimana jabatan yang ada haruslah bergilir dan semua guru memiliki peluang untuk mendapatkannya pengalaman. Begitupun berdasarkan hasil observasi, bahwa terjadi jabatan wakil kepala sekolah yang dimana waka kurikulum baru dijabat oleh guru muda yang memiliki kompetensi yaitu bapak. Musanni, S.Pd. M.Pd. Waka siswa ibu Siti Nurhani, S.Pd. Waka humas Drs. Arofiq, MM.

f. Fungsi sumber daya manusia harus ditumbuhkan sebagai satu kesatuan utama: Segala kegiatan yang secara resmi dan bahkan yang khusus guru ikut berpartisipasi aktif. Guru-guru senior membangun kepercayaan sama junior. Hal ini diyakini berdasarkan wawancara dengan kepala sekolah: guru-guru harus memiliki pengalaman yang sama, tidak peduli tua-muda, senior-junior, PNS-honorer.

\section{Implikasi pelaksanaan \\ pengelolaan sumber daya manusia (Guru) di SMA Negeri 5 Mataram}

a. Keselamatan kerja (employment security): Sebagai sekolah yang dari sejarahnya memiliki prestasi yang baik, maka dalam memilih pegawai/guru baru Smala harus meilihat jejak guru baru dengan menanyakan sekolah asal tentang kepribadiannya. Sebab, budaya kekeluargaan yang sudah ada akan tetap terjaga dengan baik. Wawancara dengan kepala sekola "Guru-guru sangat memuaskan dilihat dari cara mereka bekerja, kedekatan dengan siswa, walaupun ada konflik satu sama lain mereka tetap bekerja professional, kerja tim yang kuat, kekeluargaan yang terjalin. Intinya budaya kekeluargaan adalah ciri khas Smala, dan siapun yang datang harus mampu menyesuaiakan dengan budaya tersebut.

b. Keselektifan dalam perekrutan (selective in recruiting): Selektif pada IPK, kompetensi yang dimiliki, kepribadianya jika guru honor, begitupun guru PNS, menelusuri profil dari sekolah asalnya, prestasi apa yang diraih, kemampuan menyesuaikan diri budaya sekolah. Lebih lanjut seperti apa yang disampaikan oleh tim kurikulum 
bahwa: sekalipun belum ada mutasi dan rotasi dalam hal jabatan, namun rotasi tugas selalu dilakukan berdasarkan pertimbangan kemampuan dan kualitas kerjanya.

c. Tingkat upah yang tinggi (high wages) dan pemberian insentif (incentive pay): Segala kegiatan mengutamakan kesejahteraan guru, sehinggah membuat guru-guru memiliki semangat kerja yang tinggi, displin, melakukan kerja tim yang baik. Begitupun seperti hasil wawancara dengan guru bahasa Jerman: Kekuatan kerja tim dan nilai kekeluargaan di Smala sangat tinggi.

d. Hak kepemilikan karyawan (employee ownership): Guru-guru sangat memuaskan dilihat dari cara mereka bekerja, kedekatan dengan siswa, bekerja professional, kerja tim yang kuat, kekeluargaan yang terjalin, supel, senior sangat ramah dengan juniornya. Begitupun hasil observasi peneliti pada program PPDB (Penerimaan peserta didik baru) Online: Seluruh guru di ikut serta semua menjadi panitia. Sangat terlihat bagaimana tim dengan kekompakan mereka, guru-guru merasa memiliki kewajiban yang sama ikut serta dalam program yang sangat popular dan bergengsi bagi guru-guru di kota Mataram. Sebab, dalam program PPDB inilah persaingan siswa, gesekan politik, peluang nepotisme dan kolusi sangat tinggi.

e. Information sharing: Setiap kegiatan dan informasi baru guru-guru akan di informasikan dengan via sms, di tulis di papan pengumuman khusus guru. Jika kegiatannya diluar maka guru-guru yang akan di berikan SK (surat keputusan) untuk mengikuti kegiatan tersebut. Begitupun seperti apa yang disampaikan oleh waka humas: Setiap informasi baik itu tentang kegiatan dan tugas internal dan eksternal akan segera di informasikan ke guru-guru baik lewat sms dan papan pengumuman.

f. Partisipasi dan pemberdayaan (participation and empowerment): Rapat guru: banyak ide yang diperoleh, dinamika rapat yang sehat, aktifnya guru dalam memberikan ide dan gagasan untuk kemajuan sekolah. Pandangan yang sama dari waka kurikulum sebagai berikut: Rapat yang diadakan penuh semangat, rebutan berpendapat dari guru-guru, respon yang baik dari pimpinan sangat baik pula. Banyak ide-ide guru yang dapat di jadikan solusi dalam permasalahan sekolah.

g. Pengelolaan tim secara mandiri (self managed): Peran kepala sekolah dalam memberikan peluang guru-guru dalam berinovasi sangat besar, sejak pertama sekolah ini berdiri pemimpin sudah memberi peluang kepada guruguru untuk berinovasi. Maka, tidak heran sekolah ini memiliki kemajuan pesat dan maju di Indonesia. Hasil wawancara dengan tim kurikulum dengan peneliti juga senada dengan apa yang disampaikan sebelummnya, yaitu: Setiap guru sudah direkrut untuk bergabung kedalam masing-masing tim. Ada tim kurikulum, tim kesiswaan, tim humas, tim sarana prasarana. Hal ini memberi peluang bagi guru-guru bersaing menunjukan kualitas kerja yang efektif.

h. Pelatihan dan pengembangan ketrampilan (trainning and skill development): Sebagai pemimpin yang melanjutkan estafet kepemimpinan dari pemimpin sebelumnya. Akan menjadi resiko, beban dan motivasi bagi pemimpin selanjutnya untuk mempertahankan apa yang sudah menjadi warisan sebelimnya. Maka, sebagai pemimpin jangan sampai merusak nilai-nilai atau budaya sekolah yg sudah terbentuk melainkan 
mengembangkan agar terus maju, salah satunya memberikan kesempatan kepada guru PNS untuk melanjutkan studi S2 dengan bantuan biaya dari sekolah serta memberikan kesempatan kepada guru-guru honor untuk berinovasi dan ikut serta dalam setiap kegiatan sekolah baik pengiriman diklat dan pelatihan. Selain pendidikan sekolah juga membudayakan melek IT.

i. Cross Utilization and Cross Trainning: Pada dasarnya guru-guru SMA 5 mataram sudah cukup sejahteran dengan gaji yang mereka terima, namun untuk memberikan reward lagi semua guru-guru di ikutkan sertakan dalam berbagai tugas dan kegiatan di Smala, baik sebagai Pembina maupun panitia kegiatan lain.

j. Symbolic egalitarian: Guru-guru sangat memuaskan dilihat dari cara mereka bekerja, kedekatan mereka dengan siswa, walaupun ada konflik satu sama lain mereka tetap bekerja professional, kerja tim yang kuat, kekeluargaan yang terjalin, arisan setiap bulan dengan bergilir rumah-rumah mereka, pribadi yang supel, senior sangat ramah dengan juniornya. Intinya budaya kekeluargaan adalah ciri khas Smala, dan siapun yang datang harus

\section{PEMBAHASAN}

\section{Perencanaan pengelolaan SDM di SMA Negeri 5 Mataram}

Perencanaan dalam rangka menyiapkan keputusan-keputusan yang berkaitan dengan perencanaan. Identifikasi staf/pegawai, penempatan, penyesuaian diri, evaluasi, perbaikan, kompensasi pegawai, pemberhentian pegawai. Sehingga dalam pelaksanaan pengembangan SDM akan mendapatkan manfaat yang sesuai dengan visi misi organisasi. Perencanaan yang dimaksud merupakan proses menetapkan prioritas, rencana dan kegiatan dalam pengelolaan mampu menyesuaiakan dengan budaya tersebut. Lebih lanjut seperti yang di ceritakan oleh salah satu guru yang pertama kali mengajar sejak berdiri Smala, bahwa: rasa memiliki Smala yang membuat kami tidak terlalu memikir siap yang menjabat dan bertugas, sebab pada endingnya apapun tugasnya kami tetap kerja tim serta jiwa kekeluargaan yang sangat kuat.

k. Wage compression: Banyak kegiatan di Smala yang melibatkan seluruh guru, yang membuat guru merasa berfungsi didalam kegiatan tersebut hal inilah yang membuat guruguru merasa bahwa Smala merupakan sebuah rumah dan pekerjaan. Mereka berkerja mengutamakan kemajuan sekolah.

1. Promotion from within: Banyak hal yang mesti diperbaiki dan dikembangkan soal kompotensi guru dalam pembelajaran. Positifnya rasa kekeluargaan yang tinggi dan rasa ingin tahu dalam hal pengembangan diri, ikut aktif dalam kegiatan workshop dan pelatihan. Wawancara dengan Waka humas bahwa: Perlu diketahui bahwa guru Smala selalu menjadi pilihan menjadi guru IN (Instruktur Nasional) dan guru Guru Instruktur provinsi NTB.

tenaga kerja harus selaras dengan tujuan organisasi secara keseluruhan yang fokusnya adalah untuk mendapatkan orang yang tepat di tempat yang tepat pada waktu yang tepat (ILO, 2013: 3). Sedangkan Chatab N (2007: 51) perencanaan yang baik merupakan penyatuan dan transformasi perilaku personil dan budaya organisasi, sehingga perlunya melakukan seleksi penerimaan karyawan sesuai dengan budaya organisasi tersebut. Seperti data SMAN 5 Mataram, yaitu: Perencanan Smala yaitu a) Identifikasi guru: 1) Mempertimbangan secara bersama 
dengan unsur guru, 2) Pemenuhan kekurangan guru, 3) Penyegaran jabatan wakil kepala sekolah, 4) Mempertimbangkan harapan siswa dan harapan guru. b) Penempatan: mempertimbangkan psikologis, yaitu: 1) kesadaran, 2) komitmen dan loyalitas. c) Penyesuaian diri: mengadakan pelatihan IT. d) Evaluasi: Hasil temuan tim kecil akan dibahas dalam rapat kerja (RAKER) semester 1 atau RAKER tahunan. e) Perbaikan: Perencanaan ulang dan akan di masukan kedalam RKJM (rapat kerja jangka menengah). f) Kompensasi pegawai: bantuan dana studi s2 serta bantuan dana untuk mengikuti kegiatankegiatan seperti pelatihan. g) Pemberhentian pegawai: pendekatan klinis.

\section{Pengelolaan sumber daya manusia (Guru) di SMA Negeri 5 Mataram}

SMAN 5 Mataram mengatasi ketidakpastian atau kelemahan (infirmity), yaitu: diperkuat dan memperkokoh: 1) Menyatukan atribut Smala, 2) Meningkatkan iklim kerja yang kondusif, humanis, dan harmonis. Penyesuaian progam pendidikan secara terus-menerus agar bertahan dalam usaha meraih prestasi dengan penelitian guru, sosialisasi, dsbnya. Nilai-nilai atau budaya sekolah: 1) guru-guru PNS untuk studi S2 dengan bantuan biaya dari sekolah, 2) guru-guru honor untuk berinovasi dan ikut serta dalam setiap kegiatan sekolah baik pengiriman diklat dan pelatihan, dan membudayakan melek IT. Sasaran mutu Smala tahun pelajaran 2015/2016: a) akademik maupun non akademik minimal 40 kejuaraan, b) Sekurang-kurangnya 6 guru dapat melanjutkan studi S2, c) Sertifikasi berkualifikasi nasional dan internasional, d) Meningkatnya kemampuan berbahasa asing (Inggris-Jerman) serta dapat menggunakan Bahasa Indonesia yang baik dan benar, e) Terealisasinya penerapan SMM mengacu ISO 9001:
2008 dalam penyelenggaraan diklat dan optimalisasi elemen diklat sebagai gugus kendali mutu, f) Meningkatnya standar pelayanan prima yang berfokus pada kepuasan masyarakat dan pelanggan, sehingga meningkatkan efisiensi dan efektivitas pembelajaran.

Pemimpin mengutamakan kepentingan sekolah dari pada kepentingan pribadi dengan memberikan reword, motivasi, serta menjadi pelopor serta menyelesaikan masalah internal secara kekeluargaan. Cara-cara yang diterapkan yaitu: 1) komunikasi, 2) memotivasi, 3) kedewasaan dalam memimpin, dan 4) kesadaran dalam bekerja.

Setiap organisasi akan menghadapi berbagai tantangan, baik itu internal maupun eksternal, maka dari pada itu dibutuhkan startegi dan pengelolaan yang baik dalam mencari solusinya. Wilson, Everard, \& Geoffrey (2004: 74) kemampuan untuk mengembangkan kurikulum dengan cara mencapai tujuan sebagai perguruan tinggi, sekolah atau departemen, tentu saja tergantung pada SDM yang tersedia. Namun, sangat penting untuk memastikan bahwa ekor tidak mengibaskan anjing, bahwa isi pendidikan tidak ditentukan oleh SDM yang paling mudah tersedia, tapi bagaimana ketersediaan tersebut bisa berkualitas sesuai dengan kebutuhan pembelajaran siswa. Begitupun Peter Drucker (dalam Covey, 2004: 21) Hanya dalam beberapa ratus tahun, ketika sejarah kita ditulis dengan perspektif jangka panjang, amat mungkin bahwa kejadian yang paling penting yang akan dilihat oleh para sejarawan bukanlah teknologi, bukan internet, bukan perdagangan secara elektronik, melainkan perubahan dalam kondisi manusiawi, yang belum pernah terjadi sebelumnya. 


\section{Analisis teknik evaluasi pengelolaan sumber daya manusia (Guru) di SMA Negeri 5 Mataram}

Cara aplikatif Smala dalam evaluasi:

a) Kemampuan kerja: 1) pengembangan diri, 2) kegiatan workshop dan pelatihan, dan 3) kerja sama. Adapun hal-hal yang menjadi prestasi, yaitu: 1) memiliki guru IN dan guru Instruktur provinsi, dan hubungan kedekatan siswa dengan guru sangat terjalin harmonis, b) Kehadiran guru, yaitu: 1) kesadaran pribadi, 2) reward, dan 3) program unggulan $5 \boldsymbol{S}$, c) Kepatuhan disiplin kerja: 1) nilai kesadaran akan tugas, 2) aturan tidak terlalu ketat, dan 3) pendelegasian jika berhalangan. d) Rasa tanggung jawab: program kerja, silabus, RPP sudah terjadwal khusus diawal tahun pelajaran secara serentak di bawah kontrol kepala sekolah, begitupun kegiatan membuat soal Mid, UTS, UAS, Try Out, dan sebagainya mengikuti kalender pendidikan, e) Hubungan kerja sama: kekeluargaan dan membantu guru secara moril dan materi, f) Kelakuan di dalam dan di luar dinas: 1) kedekatan dengan siswa, 2) kepetingan sekolah jadi utama, 3) kekeluargaan yang terjalin, 6) pribadi yang supel, dan 7) senior sangat ramah dengan juniornya. g) Prakarsa (inisiatif) yaitu guru dituntut untuk kreatif, inovatif, mandiri, dan kreasi. h) Kepemimpinan, yaitu: 1) prinsip yang luwes, 2) belajar cara pemimpin sebelumnya, 3) inovasi, dan) 4) teladan bagi guru. i) Pekerjaan pada umumnya, yaitu: 1) pembina dalam kegiatan ekstrakulikuler, panitia/mengawas waktu Mid, UTS dan UAS, 3) pelatihan, seminar, sosialisasi.

Dalam Pengelolaan sumber daya manusia (Ellitan, 2002: 70), harus menciptakan psikologi lingkungan yang positif seperti: 1) Meningkatkan bobot dan nilai pekerjaan, 2) Meningkatkan keamanan dan kenyamanan kondisi kerja, 3) Memelihara tingkat upah dan sistem imbalan yang memadai, 4)
Menciptakan kepastian kerja, 5) Supervisi yang kompeten, 6) Menciptakan peluang yang lebih besar untuk maju dan berkembang, 7) Adanya umpan balik (feedback), dan 8) Lingkungan sosial yang positif dan keadilan. Menurut Chatab (2007: 79) sebagai respon dari fungsi pengendalian dan fungsi perbaikan, kegiatan perbaikan segera dilaksanakan untuk meningkatakan efektifitas dan efisiensi, yaitu: dimensi proses dan dimensi hasil. Begitupun hasil penelitian (Sukoco \& Ajeng, 2005: 1) upaya yang dilakukan untuk mengatasi kesulitan antara lain: meningkatkan kompetensi melalui partisipasi aktif dalam kelompok kerja Kepala Sekolah (K3S) dan kelompok kerja guru (KKG).

\section{Tindak lanjut dari hasil pengelolaan sumber daya manusia (Guru) di SMA Negeri 5 Mataram}

Smala merespon perubahan yang terjadi pada dunia pendidikan, baik itu perubahan pada aturan daerah maupun pada aturan pusat dengan mempersiapkan prioritas melet IT. Berbagai perubahan harus bisa di respon secara tepat dengan cara menyesuaikannya analisis SWOT. Adapun cara yang dilakukakan di Smala, yaitu: 1) membangun kerja tim, 2) kesejahteraan, 3) jabatan secara periodik, dan 4) fokus tugas profesional guru. Di samping itu, secara psikologis yaitu pendekatan pribadi, sikap positif. Pemimpin yang baik adalah menampung segala aspirasi bawahan (komunkasi klinis). Secara psikologis manajeman mempertimbangkan 4 model manajamen, seperti penelitian Dweck (2006: 196): 1) Penelitiannya dengan 2 kelompok mahasiswa dengan midset tetap dan mahasiswa dengan midset berkembang pada mahasiswa manajemen. Dimana mahasiswa yang bermidset berkembangan melakukan keterampilan manajemen (melatih, pengangkatan, 
evaluasi kinerja dan pengembangan), 2) Penelitian 2 kelompok siswa yaitu 5 siswa yang berprestasi dengan 5 siswa yang memiliki prestasi terendah. Penelitian dilaksanakan di sebuah sekolah favorit dan maju di USA, selama 1 semester dengan mendatangkan guruguru dari sekolah lain. Eksperimen yang dilakukan adalah merubah midset guruguru tersebut bahwa 5 siswa yang memiliki prestasi terendah di ubah menjadi siswa yang sangat berprestasi di sekolah tersebut begitupun sebaliknya dan hasilnya "yang memiliki prestasi terendah manjadi juara kelas semuannya". Maknanya bahwa manajemen yang baik yang mampu memajukan sebuah organisasi dengan merubah midset para personil didalamnya, 3) Perilaku midset tetap pada pemimpin organisasi dengan memetakan prioritas SDM mana yang superior dan yang biasa akan membawa kehancuran perusahan ketika rezimnya berakhir. Sebab, SDM yang ada tidak lagi memiliki pengalaman, dan 4) Memberikan penghargaan pada karyawan yaitu kepuasan dan tanggung jawab dengan ukuran kesejahteraan tertentu jelas berefek pada produktivitas dan kinerja.

Sekalipun banyak faktor lain yang bisa membuat sebuah sekolah maju, namun ada manusia didalamnya yaitu guru yang berperan penting dalam kemajuan sekolah. Tantangan sebuah organisasi sangat beragam dalam usaha kemajuannya. Maka, perlu mempertimbangakan Simamora (2001) model-model pengembangan SDM diklasifikasikan: 1) model manejerial, 2) model humanistic, 3) model perilaku, 4) model financial. Sebab, 4 aspek ini mampu mendukung langkah-langkah kemajuan organisasi.

Berapa hal yang harus diketahui yang sudah dilakukan di Smala, yaitu: 1) Tendensi yang baik sudah terbina; 2)
Pendekatan kepribadian; 3) Pengawasan rutin; 4) sumbangan infak. Sebagai sekolah dengan nama besar (maju), tidaklah datang dengan inovasi berlebihan, melainkan: 1) memperkuat sistem yang sudah berjalan, 2) menambah yang kurang, 3) memperbaiki yang sakit, dan 4) menyempurnakan yang sudah ada. Contohya: Jika kekurangan guru atau membutuhkan guru yang sudah memiliki prestasi. Ada beberapa point untuk membuat Smala mejadi sekolah favorit dan sudah kami terapkan, yaitu: 1) rasa kekeluargaan, baik kepala sekolah, guru, Tu, siswa, dan orang tua; 2) membangun komunikasi yang intens dan penuh humoris; 3) setiap guru yang memiliki kelebihan pada potensi khusus; dan 4) seluruh guru harus menerima perbedaan agar terhindar konflik.

Misi yang diprogramkan agar meningkatkan efektivitas dan efesiensi sekolah. Mewujudkan hubungan penuh kekeluargaan dengan seluruh guru. Seperti penelitian Nurhikmahyanti \& Tyas (2014: 89) perlunya sebuah sekolah melakukan evaluasi diri sekolah dengan cara internal adalah (1) SDM; (2) koordinasi antar stakeholder; (3) komunikasi antar warga sekolah, secara eksternal dukungan dari Dinas dan motivasi dari LPMP.

\section{Implikasi pelaksanaan pengelolaan sumber daya manusia (Guru) di SMA Negeri 5 Mataram}

SMAN 5 Mataram selektif dalam memilih dan merekrut, yaitu: 1) kompetensi, 2) kepribadianya, 3) profil, 4) prestasi, dan 5) kemampuan menyesuaikan diri. Pemberian insentif akan memberikan kemampuan lebih selektif dalam menemukan orang yang dapat dilatih dan bertanggung jawab terhadap sekolah. Sudah merupakan suatu tendensi bahwa uang sering digunakan untuk memecahkan masalah. Guru merasakan bahwa SMAN 5 
merupakan bagian dari kehidupan, sehinggah berkerja dengan sepenuh hati. Guru-guru memiliki informasi yang dibutuhkan untuk tercapainya suatu kesuksesan sekolah. Dalam rapat, guruguru memberikan ide yang membangun untuk kemajuan sekolah. SMAN 5 memiliki tim yang kuat. Pelatihanpelatihan untuk menunjang profesionalitas dengan memberikan kesempatan seluas-luasnya dalam pelatihan dan pengembangan keahlian. Selain pekerjaan pokok yaitu mengajar, guru-guru memiliki perkerjaan lain dalam usaha kemajuan sekolah. Komitmen dan kerja sama guru mengutamakan kepentingan sekolah dari pada kepentingan pribadi dalam bekerja.

Pfeffer dalam (Elitan, 2002: 8) menegaskan bahwa suatu keunggulan kompetitif dapat dicapai melalui pengelolaan sumber daya manusia yang dimiliki perusahaan secara efektif. Hal ini dapat diperoleh dengan menerapkan

\section{SIMPULAN DAN SARAN}

\section{Simpulan}

Perencanaan SDM: a) Secara demokratis, b) Penempatan guru profesional lebih mempertimbangkan psikologis, c) SDM memiliki ke ahlian di bidang IT, d) Tim kecil (seluruh wakil kepala sekolah) untuk menemukan permasalahan, e) Rapat kerja tahunan (RAKER), f) Kesejahteraan, g) Kekeluargaan. Pengelolaan SDM: a) Memperkuat atribut Smala, Meningkatkan iklim kerja kebersamaan, keteladanan, dan (5S), b) Membudayakan melek IT, c) Memiliki sasaran mutu, d) Supervisi klinis. Teknik evaluasi SDM: a) Kerjasama, b) kesadaran pribadi, reward dan penerpan program $5 S$, c) aturan tidak terlalu ketat, d) Program kurikulum terjadwal, e) Fokus 4 kompetensi guru, g) pemanfaatan guru produktif untuk kreatif, dan Guru IN (Instruktur Nasional praktik-praktik secara saling berkaitan karena sulit untuk menangani suatu tindakan bila hanya diterapkan secara terpisah. Sekolah mengatur proses pendidikan sesuai dengan potensi lingkungan yang ada baik dari perencanaan, pelaksanaan, monitoring serta pengambilan keputusan kebijakan. Tetapi segala macam pengelolaan pendidikan yang dibuat tetap harus mengacu pada Standar Nasional Pendidikan (SNP) mulai dari standar kelulusan, isi, proses, sarana prasarana, pendidik dan tenaga pendidik, pengelolaan, pembiayaan, hingga standar penilaian sesuai dengan Peraturan Pemerintah (PP) Nomor 19 Tahun 2005 tentang Standar Nasional Pendidikan (SNP), berfungsi sebagai dasar bagi perencanaan, pelaksanaan, dan pengawasan pendidikan pada setiap satuan pendidikan dalam rangka mewujudkan pendidikan nasional yang bermutu.

\& Regional), h) pemimpin partisipan, i) Kegiatan menjadi Pembina, panitia, mengawas, pelatihan, seminar, sosialisasi, dan sebagainnya. Tindak lanjut dari hasil pengelolaan SDM: a) mempertimbangkan 4 model manajemen pengelolaan SDM, Mempertimbangkan kondisi internal dan eksternal, c) Prioritas melet IT, d) Berbagai perubahan direspon secara tepat dengan cara menyesuaikannya, e) Analisis SWOT, f) Menyatukan persepsi, g) Melakukan koordinasi, h) Pertimbangkan psikologis, i) Memperkuat sistem yang sudah berjalan, j) Fokus visi misi sekolah. Implikasi pelaksanaan pengelolaan SDM: a) kekeluargaan, b) rotasi tugas, c) pemberian insentif, d) tim yang kuat, e) komitmen mengutamakan kepentingan sekolah dari pada kepentingan pribadi.

Saran 
1. Guru, diharapkan tetap membangun kerja sama tim, nilai kekeluargaan, dan melaksanakan tugas mengajar yang lebih baik dengan mengacu pada 4 (empat) kompetensi yang melekat pada diri guru, yaitu kompetensi

\section{DAFTAR PUSTAKA}

Chatab, N. 2007. Manajemen Diagnosis, Metode Teruji Meningkatkan Keunggulan Organisasi. Jakarta: Serambi Ilmu Semesta.

Covey S R. 2004. THE 8th HABIT Melampaui Efektivitas, Menggapai Keagungan. New York: A Fire-Side Book.

Damaianti dan Syamsuddin. 2009. Metode Penelitian Pendidikan Bahasa. Bandung: Remaja Rosdakarya.

Damayani, Purnamasari dan Kusdaryani. 2016. Penguatan Kultur Sekolah Untuk Mewujudkan Pendidikan Ramah Anak. Semarang: Fakultas Ilmu Pendidikan Universitas PGRI Semarang. Cakrawala Pendidikan, Februari 2016, Th. XXXV, No. 1.

Depdiknas (Kemendiknas). 2014. 35 Sekolah SMA Terbaik di Indonesia Versi Depdiknas (Kemendiknas). Jakarta: Depdiknas (Kemendiknas). Online. http://www.pendidikan-

diy.go.id/dinas_v4/?view=v_berita\&id sub=3223. Senin, 29 Desember 2015.

Dweck. 2006. Change Your Mindset Change Your Life. New York: Random House. Terjemahan: PT. Serabi Ilmu Semesta.

Ellitan, Lena. 2002. Praktik-Praktik Pengelolaan Sumber Daya Manusia dan Keunggulan Kompetitif Berkelanjutan. Jurnal Manajemen \& Kewirausahaan Vol. 4, No. 2, September 2002: 65-76. Jurusan Ekonomi Manajemen, Fakultas Ekonomi Universitas Kristen Petra

ILO. 2013. Manajemen Sumber Daya Manusia untuk Kerjasama dan Usaha yang Sukses. Jurnal Internasional. padagogik, kepribadian, profesional, dan sosial.

2. Peneliti selanjutnya, agar dapat melakukan kajian aspek pengelolaan SDM yang belum terungkap dalam penelitian ini.

Jakarta: Keberlanjutan melalui perusahaan yang kompetitif dan bertanggung jawab (SCORE) Modul 4.

Mulyasa. E. 2007. Manajemen Berbasis Sekolah. Bandung: PT. Remaja Rosdakarya.

Pranoto. 2013. Pengaruh Pembinaan Berkelanjutan, Supervisi Pengawas Dan Motivasi Kerja Terhadap Kinerja Guru Di UPT Disdikpora Kecamatan Mayong Kabupaten Jepara. Semarang: PPs Manajemen Pendidikan IKIP PGRI Semarang. JMP, Volume 2 Nomor 1, April 2013.

Puspitasari dan Mangkunegara. 2015. Kecerdasan Emosi, Stres Kerja, Dan Kinerja Guru SMA. Banten: Universitas Mercu Buana. Jurnal Kependidikan, Volume 45, Nomor 2, November 2015, Halaman 142-155

Simamora, H. 2001. Manajemen Sumber Daya Manusia. Yogyakarta: STIE YKPN.

Sumintono. 2013. Sekolah Unggulan: Pendekatan Pengembangan Kapasitas Sekolah. Fakulti Pendidikan Universiti Teknologi Malaysia, Skudai 81310Johor Bahru Malaysia. JMP, Volume 2 Nomor 1, April 2013.

Suryosubroto. 2004. Manajemen Pendidikan di Sekolah. Jakarta: PT. Rinekan Cipta.

Tyas dan Nurhikmahyanti. 2014. Penerapan Program Evaluasi Diri Sekolah (EDS) (Studi Kasus Di SMA Negeri 1 Gresik). Surabaya: Program Studi Manajemen Pendidikan, Fakultas Ilmu Pendidikan, Universitas Negeri Surabaya. Jurnal Inspirasi Manajemen 
Pendidikan, Vol. 3 No. 3, Januari 2014, hlm. 89-99.

Wahjosumidjo. 2007. Kepemimpinan Kepala Sekolah. Jakarta: PT Grafindo Persada.

Wilson, I., K.B. Everard., \& Geoffrey, M. 2004. Effective School Management Fourth Edition. California: Paul Chapman Publishing. 